\title{
RESEARCH
}

\section{Adverse effects of medical cannabinoids: a systematic review}

\author{
Tongtong Wang MSc, Jean-Paul Collet PhD MD, Stan Shapiro PhD, Mark A. Ware MBBS MSc
}

$\infty \quad$ See related article page $\mathrm{i} 685$

\section{ABSTRACT}

Background: The therapeutic use of cannabis and cannabisbased medicines raises safety concerns for patients, clinicians, policy-makers, insurers, researchers and regulators. Although the efficacy of cannabinoids is being increasingly demonstrated in randomized controlled trials, most safety information comes from studies of recreational use.

Methods: We performed a systematic review of safety studies of medical cannabinoids published over the past 40 years to create an evidence base for cannabis-related adverse events and to facilitate future cannabis research initiatives. We critically evaluated the quality of published studies with a view to identifying ways to improve future studies.

Results: A total of 321 articles were eligible for evaluation. After excluding those that focused on recreational cannabis use, we included 31 studies ( 23 randomized controlled trials and 8 observational studies) of medical cannabis use in our analysis. In the 23 randomized controlled trials, the median duration of cannabinoid exposure was 2 weeks (range 8 hours to 12 months). A total of 4779 adverse events were reported among participants assigned to the intervention. Most ( $4615[96.6 \%]$ ) were not serious. Of the 164 serious adverse events, the most common was relapse of multiple sclerosis ( 21 events [12.8\%]), vomiting ( 16 events [9.8\%]) and urinary tract infection (15 events [9.1\%]). The rate of nonserious adverse events was higher among participants assigned to medical cannabinoids than among controls (rate ratio [RR] 1.86, 95\% confidence interval [CI] 1.57-2.21); the rates of serious adverse events did not differ significantly between these 2 groups (RR 1.04, 95\% Cl 0.78-1.39). Dizziness was the most commonly reported nonserious adverse event (714 events [15.5\%]) among people exposed to cannabinoids.

Interpretation: Short-term use of existing medical cannabinoids appeared to increase the risk of nonserious adverse events. The risks associated with long-term use were poorly characterized in published clinical trials and observational studies. High-quality trials of long-term exposure are required to further characterize safety issues related to the use of medical cannabinoids.

Une version française de ce résumé est disponible à l'adresse www.cmaj.ca/cgi/content/full/I78/I3/r669/DCI

CMAJ 2008;178(13):1669-78

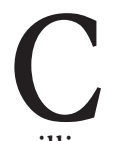
annabis (Cannabis sativa) is widely used as a recreational drug, with an estimated worldwide annual prevalence (defined as use at least once per year) of I6o million. ${ }^{1}$ Cannabis preparations have also been used medicinally for thousands of years. In the past 40 years the active ingredients of cannabis, $\Delta$-9-tetrahydrocannabinol and cannabidiol, and other derivatives (termed "cannabinoids") have been identified and characterized, ${ }^{2}$ and it is becoming clear that cannabinoids have considerable therapeutic potential. ${ }^{3}$

In Canada, 4 cannabinoid products are currently available for medical use, more than in any other country worldwide. These are: a herbal cannabis extract (marketed as Sativex [GW Pharmaceuticals], which contains $\Delta$-9-tetrahydrocannabinol and cannabidiol in an oromucosal spray); dronabinol (synthetic $\Delta$-9-tetrahydrocannabinol, marketed as Marinol [Solvay Pharmaceuticals]); nabilone (a synthetic derivative of $\Delta$-9tetrahydrocannabinol, marketed as Cesamet [Valeant Pharmaceuticals International]); and the herbal form of cannabis (available legally through the Medical Marijuana Access Regulations). ${ }^{4,5}$ In Canada, dronabinol and nabilone are indicated for chemotherapy-induced nausea and vomiting, dronabinol is approved for HIV-associated anorexia, and oromucosal $\Delta$-9tetrahydrocannabinol-cannabidiol is conditionally approved for neuropathic pain in multiple sclerosis and cancer pain.

The efficacy of these cannabinoid medicines has been evaluated in randomized controlled trials. In addition, the use of cannabinoids as antiemetics has been systematically reviewed, and potential efficacy has been suggested. ${ }^{6}$ There has also been considerable interest in the use of cannabinoids as adjunctive therapy for pain management, and several small randomized controlled trials have been published recently. Dronabinol and oromucosal $\Delta$-9-tetrahydrocannabinolcannabidiol have been proven effective for central neuropathic pain associated with multiple sclerosis. ${ }^{7-11}$ Oromucosal $\Delta$-9-tetrahydrocannabinol-cannabidiol reduced pain associated with rheumatoid arthritis, ${ }^{12}$ and nabilone was effective for pain associated with fibromyalgia. ${ }^{13}$ A recent review supported further consideration of cannabinoids for

From the Departments of Epidemiology and Biostatistics (Wang, Collet, Shapiro), Anesthesia (Ware) and Family Medicine (Ware), McGill University, Montréal, Que.; the Centre for Healthcare Innovation and Improvement (Collet), Children's and Women's Health Centre, University of British Columbia, Vancouver, BC; and the Alan Edwards Centre for Research on Pain (Ware), McGill University, Montréal, Que. 
chronic pain but was less encouraging for their use in acute pain conditions. ${ }^{3}$

In addition to the use of prescription cannabinoids, the medical use of smoked herbal cannabis is substantial: an estimated 10\%-20\% of patients with multiple sclerosis, chronic noncancer pain, HIV/AIDS and epilepsy report smoking cannabis for therapeutic purposes. Smoked cannabis has been found to be safe $\mathrm{e}^{14}$ and effective ${ }^{15}$ for HIV-associated disorders. As of October 2007, 226r patients in Canada were authorized to use herbal cannabis for medical purposes under the Medical Marihuana Access Regulations. ${ }^{16}$

With this rising interest in therapeutic use, the safety of cannabinoids is an emerging source of concern for many physicians. The safety of therapeutic agents can be studied by a variety of methodologic approaches, including randomized controlled trials, observational studies and pharmacovigilance studies. ${ }^{17,18}$ The adverse effects of cannabis have been summarized in several reports, ${ }^{19-24}$ and systematic reviews have found cannabis to be a risk factor for psychosis ${ }^{25}$ cancer $^{26}$ and neurocognitive effects, ${ }^{27}$ but these reports all focused on the recreational use of cannabis.

We report here a systematic review of the published adverse events of medical cannabinoid use. Our primary objective was to create a database of known adverse events related to the medical use of cannabis to inform physicians, policymakers and the public. In addition, we sought to critically evaluate the quality of published studies to guide future studies on the safety of medical cannabis use.

\section{Methods}

\section{Search strategy}

We conducted a comprehensive search of Ovid MEDLINE (January I 966 to week 5 of October 2007), PsycINFO (January I967 to week 5 of October 2007) and EMBASE (January I980 to week 42 of 2007), using the following key words: "bhang," "charas," "cannabis," "cannabinoids," "dagga," "ganja," "hashish," "hemp," "marijuana," "marihuana" and "tetrahydrocannabinol or THC." We included studies that specified "human," "safety," "case report," "case-control," "cohort," "cross-sectional," "crossover," "randomized controlled trial," "longitudinal" or "epidemiological" in the title or key words. The detailed search strategy is presented in Appendix I (available at www.cmaj.ca/cgi/content/full/I78/I3/I669 /DC2). We identified additional studies from the reference lists of selected articles and review articles.

\section{Study selection}

Two reviewers (T.W. and M.W.) independently reviewed the titles and abstracts for relevance according to the following criteria. We included randomized controlled trials evaluating the safety and efficacy of cannabis if adverse events were quantified. We included observational studies in which cannabis represented the main exposure, provided the outcome of interest was adverse events. We included case reports if they described adverse events in people exposed to cannabis.

We excluded studies that focused on adverse effects of cannabis occurring in combination with other agents, those that involved synthetic cannabinoids (e.g., nabilone, levonantradol), those that studied treatment of cannabis dependence or cannabis cessation, and those that focused on the effects of cannabis on school achievement, marriage, criminal behaviour (e.g., homicide, violent crimes) or hormone levels. We also excluded studies of mechanisms of action, studies of pharmacodynamic or pharmacokinetic effects and studies with other basic experimental designs. Finally, we excluded studies published in languages other than English, French, Spanish or German. The 2 primary reviewers resolved disagreements regarding study selection through discussion. We obtained the full text of papers identified on the basis of titles and abstracts and applied additional criteria for final selection of the studies for review and meta-analysis.

Finally, we classified the selected articles by reason for cannabis use (medical or recreational) and by study design. For this review, we evaluated only studies focusing on the safety of cannabinoids used for medical purposes.

\section{Assessment of study quality}

Two raters (T.W. and one other person) independently assessed study quality. We used the scale proposed by Jadad and associates ${ }^{28}$ to assess the methodologic quality of randomized controlled trials and the Downs and Black checklist ${ }^{29}$ to assess the quality of observational studies involving a control group. The raters resolved disagreements regarding quality assessment through discussion.

\section{Data extraction}

We identified serious adverse events and nonserious adverse events according to the definitions recommended by the International Conference on Harmonisation of Technical Requirements for Registration of Pharmaceuticals for Human Use (referred to hereafter as the International Conference on Harmonisation)..$^{30}$ Under these guidelines, a "serious adverse event" is defined as any untoward medical occurrence that requires admission to hospital or prolongation of an existing admission, that causes congenital malformation, that results in persistent or significant disability or incapacity, that is life-threatening or that results in death. A "nonserious adverse event" is defined as any untoward medical occurrence in a patient or participant; the event need not have a causal relation to the treatment. We used the guidelines of the International Conference on Harmonisation to define the expectedness of an adverse event, whereby an "unexpected" adverse event is one for which "the nature or severity ... is not consistent with the applicable product information." ${ }^{30} \mathrm{We}$ coded all identified adverse events using the Medical Dictionary for Regulatory Activities headings "system organ classes" and "preferred terms." ${ }^{31}$ One of us (T.W.) performed the data extraction and Medical Dictionary for Regulatory Activities coding, and a second medically qualified reviewer (M.W.) verified the data extraction and coding.

\section{Data analysis}

We used Medical Dictionary for Regulatory Activities coding $^{31}$ and information about study design to categorize seri- 
ous and nonserious adverse events. For descriptive purposes, we estimated the incidence rates of serious and nonserious adverse events in randomized controlled trials by dividing the number of events by the corresponding cumulative person-years. To generate a cumulative estimate of person-years, we combined the person-years for all participants exposed to cannabis. We applied the same logic to estimate total person-years exposed to the control. For participants in crossover trials, the person-years of exposure could be applied more than once to the cumulative estimate of person-years. When the duration of exposure for a participant who withdrew from a randomized controlled trial was unclear, we estimated the person-year contribution of that person as half of the complete follow-up time per person in the trial.

We conducted a random-effects meta-analysis to assess the occurrence of adverse events, serious and nonserious, among participants assigned to cannabis exposure or control. We derived rate ratios (RRs) and variances for each trial and added a correction value of 0.5 to each count in the case of zero events. We computed point estimates with corresponding $95 \%$ confidence intervals (CIs) for pooled RRs. ${ }^{32}$ We assessed all pooled estimates for heterogeneity, using the heterogeneity $\chi^{2}$ test and the $I^{2}$ statistic (the percentage of variation across studies that is due to heterogeneity ${ }^{33}$ ). We prospectively studied adverse events according to the type of cannabis preparation (oromucosal $\Delta$-9-tetrahydrocannabinol-cannabidiol, oral $\Delta$-9-tetrahydrocannabinol, oral $\Delta$-9-tetrahydrocannabinolcannabidiol) and performed predefined subgroup analyses (for duration of exposure [ $>2$ weeks, $\leq 2$ weeks], study design [parallel, crossover] and study population [people with and without cancer]) within each medical cannabis preparation. For nonserious adverse events, we also estimated pooled RRs and corresponding $95 \%$ CIs for each system organ class.

\section{Results}

We identified a total of 1720 articles with the initial search strategy (Figure I). We excluded I443 articles that did not satisfy the inclusion and exclusion criteria, including 28 randomized controlled trials that did not report quantifiable adverse event data. One trial was presented in 2 separate publications: one with safety data reported up to $5^{\text {th }}$ week ${ }^{10}$ and the other with safety data collected from the I6th to the $52 \mathrm{nd}$ week; ${ }^{11}$ we counted these 2 articles as a single trial. We excluded II case reports and 2 observational epidemiological studies because of the language of publication.

We identified an additional 57 studies (49 case reports and 8 observational studies) by examining the reference lists of review articles. We also included one in-press randomized controlled trial (which has now been published). ${ }^{7}$

We therefore identified a total of 32I studies regarding safety issues of cannabis published between January 1966 to October 2007. Of these, 290 ( $90.3 \%$ ), consisting of 92 observational studies and 198 case reports, focused on recreational use; for the purposes of this study, we did not consider these studies further. We analyzed data from the remaining $3 \mathrm{I}$ studies ( $9.7 \%), 23$ randomized controlled trials and 8 observational studies, in which the safety of medical cannabinoid use could be evaluated.

For the 23 randomized controlled trials of medical cannabinoid use, ${ }^{7-12,34-51}$ summarized in Table $\mathrm{I}$, the median Jadad score was $4 / 5$ (range 2 to 5 , where higher score indicates better quality). Four of the trials did not provide information on the number of participants withdrawn or the reasons for withdrawal. ${ }^{34-37}$ Seventeen (74\%) of the 23 trials had a sample size less than Ioo, and II (48\%) of them had fewer than 50 participants. The median duration of cannabinoid exposure was 2 weeks (range 8 hours to 12 months). The total number of participants exposed to cannabinoid therapy was 1932, yielding 445 person-years of cannabinoid exposure. Among the 1209 people assigned to control groups (either placebo or standard care), there were 239 person-years of exposure; of these, II2I people (accounting for 236 person-years) received placebo. (The total number of participants in the treatment and control groups is

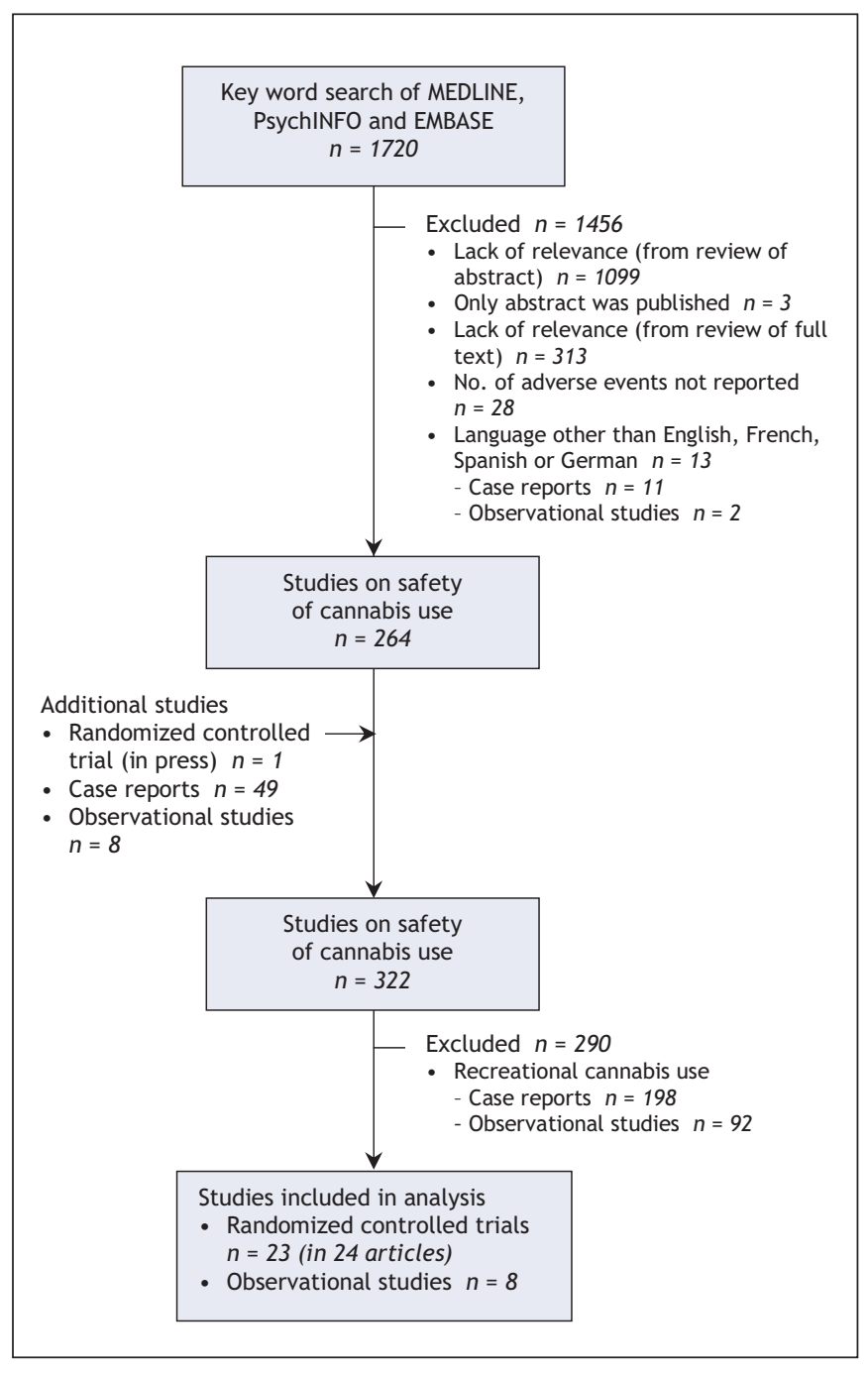

Figure 1: Retrieval and selection of studies of safety of cannabinoid preparations. 
greater than the sum of sample sizes in Table I because participants in the crossover trials contributed to both group totals.)

With the exception of one trial involving 12 healthy cannabis-naive volunteers ${ }^{48}$ all trials involved patients with medical conditions, such as cancer or multiple sclerosis, and use of cannabis was intended to address symptoms such as nausea and vomiting induced by chemotherapy or pain (see Table I). Oral $\Delta$ - 9 -tetrahydrocannabinol or $\Delta-9$ tetrahydrocannabinol-cannabidiol (I5 trials) and oromucosal $\Delta$-9-tetrahydrocannabinol-cannabidiol (8 trials) were the cannabinoid preparations studied. No randomized controlled trials of medical cannabis administered by smoking were included in the review, since adverse events were not quantified in any such studies.

\section{Adverse events}

Through our review, we identified I64 serious adverse events among people assigned to cannabinoid therapy and 60 among controls. There was no evidence of a higher incidence of serious adverse events following medical cannabis use compared with control (rate ratio [RR] I.04, 95\% CI o.78-
I.39). The serious adverse events are categorized in Table 2. Respiratory ( $\mathrm{I} 6.5 \%$ ), gastrointestinal ( $16.5 \%$ ) and nervous system disorders (15.2\%) were the most frequently reported categories of serious adverse events among those assigned to cannabinoids, whereas nervous system disorders (30.0\%) were the most frequently reported among controls. Relapse of multiple sclerosis (2I events [12.8\%]), vomiting (I6 events $[9.8 \%]$ ) and urinary tract infection (15 events [9.1\%]) were the most commonly reported serious adverse events among people assigned to receive cannabinoids. The majority of serious adverse events ( $\mathrm{I}_{3} 3$ among cannabinoid users and 58 among controls) were reported in 2 trials, which contributed $88.8 \%$ of person-years of cannabinoid exposure and $84 . \mathrm{I} \%$ of exposure to control. ${ }^{10,11,44}$

Fifteen deaths (3.4 per Ioo person-years) were reported among cannabinoid users ( 3 because of pneumonia, I because of cervix carcinoma, I because of convulsion, Io not specified), and 3 deaths (I.3 per Ioo person-years) were reported among controls (I pneumonia, I myocardial ischemia, I not specified). The difference in death rate between these 2 groups was not statistically significant (RR 2.66, 95\% CI 0.77-9.28). The mortality RR was mainly influenced by one

Table 1: Randomized controlled trials of medical cannabinoid preparations, published between 1966 and late 2007 and reporting detailed adverse event data, by mode of administration (part 1)

\begin{tabular}{|c|c|c|c|c|c|c|c|}
\hline $\begin{array}{l}\text { Mode of } \\
\text { administration; } \\
\text { study design }\end{array}$ & Reference & $\begin{array}{c}\text { Condition } \\
\text { characterizing } \\
\text { study population }\end{array}$ & $\begin{array}{l}\text { Sample } \\
\text { size }\end{array}$ & $\begin{array}{l}\text { Age, mean } \\
\text { (range), yr }\end{array}$ & $\begin{array}{l}\text { Sex, } \\
\% \text { male }\end{array}$ & $\begin{array}{l}\text { Duration of } \\
\text { exposure }\end{array}$ & $\begin{array}{l}\text { Most frequently reported } \\
\text { adverse event: } \mathrm{n} / \mathrm{N}(\%)^{*}\end{array}$ \\
\hline \multicolumn{8}{|c|}{$\begin{array}{l}\text { Oromucosal spray }(\Delta-9- \\
\text { tetrahydrocannabinol-cannabidiol) }\end{array}$} \\
\hline \multirow[t]{5}{*}{$\begin{array}{l}\text { Parallel randomized } \\
\text { controlled trial }\end{array}$} & Blake et al. ${ }^{12}$ & $\begin{array}{l}\text { Rheumatoid } \\
\text { arthritis }\end{array}$ & 58 & 62.8 & 21 & 5 wk & $\begin{array}{l}\text { Nervous system disorders: } \\
13 / 23(57)\end{array}$ \\
\hline & Collin et al. ${ }^{38}$ & Multiple sclerosis & 189 & 49.1 & 40 & 6 wk & $\begin{array}{l}\text { Nervous system disorders: } \\
68 / 169(40.2)\end{array}$ \\
\hline & $\begin{array}{l}\text { Nurmikko } \\
\text { et al. }{ }^{7}\end{array}$ & Neuropathic pain & 125 & 53 & 41 & 5 wk & $\begin{array}{l}\text { Gastrointestinal disorders: } \\
40 / 101(39.6)\end{array}$ \\
\hline & Rog et al. ${ }^{8}$ & Multiple sclerosis & 66 & $49(27-72)$ & 21 & 4 wk & $\begin{array}{l}\text { Nervous system disorders: } \\
\text { 22/56 (39) }\end{array}$ \\
\hline & Wade et al. ${ }^{39}$ & Multiple sclerosis & 160 & $51(27-74)$ & 38 & 6 wk & $\begin{array}{l}\text { Nervous system disorders: } \\
45 / 112(40.2)\end{array}$ \\
\hline \multirow[t]{3}{*}{$\begin{array}{l}\text { Crossover randomized } \\
\text { controlled trial }\end{array}$} & Berman et al. ${ }^{40}$ & $\begin{array}{l}\text { Brachial plexus } \\
\text { avulsion }\end{array}$ & 48 & $39(23-63)$ & 96 & $2 w k$ & $\begin{array}{l}\text { Nervous system disorders: } \\
48 / 62 \text { (77) }\end{array}$ \\
\hline & Tomida et al. ${ }^{37}$ & Glaucoma & 6 & 55 & 100 & $18 \mathrm{~h}$ & $\begin{array}{l}\text { Gastrointestinal disorders: } \\
5 / 18(28)\end{array}$ \\
\hline & Wade et al. ${ }^{41}$ & Neuropathic pain & 21 & 48 & 50 & $2 w k$ & $\begin{array}{l}\text { Nervous system disorders: } \\
11 / 36(31)\end{array}$ \\
\hline \multicolumn{8}{|c|}{$\begin{array}{l}\text { Oral ( } \Delta \text {-9-tetrahydrocannabinol or } \\
\Delta \text {-9-tetrahydrocannabinol-cannabidiol) }\end{array}$} \\
\hline \multirow[t]{4}{*}{$\begin{array}{l}\text { Parallel randomized } \\
\text { controlled trial }\end{array}$} & Buggy et al. ${ }^{42}$ & $\begin{array}{l}\text { Postoperative } \\
\text { pain }\end{array}$ & 40 & 44.8 & 0 & $24 \mathrm{~h}$ & $\begin{array}{l}\text { Nervous system disorders: } \\
34 / 82(41)\end{array}$ \\
\hline & Frytak et al. ${ }^{43}$ & $\begin{array}{l}\text { Chemotherapy- } \\
\text { induced nausea }\end{array}$ & 116 & 61 & 60 & $4 d$ & $\begin{array}{l}\text { Nervous system disorders: } \\
56 / 78(72)\end{array}$ \\
\hline & Strasser et al. ${ }^{44}$ & $\begin{array}{l}\text { Cancer-related } \\
\text { anorexia-cachexia } \\
\text { syndrome }\end{array}$ & 243 & 61 & 54 & 6 wk & $\begin{array}{l}\text { Gastrointestinal disorders: } \\
70 / 187(37.4)\end{array}$ \\
\hline & $\begin{array}{l}\text { Timpone } \\
\text { et al. } 45\end{array}$ & $\begin{array}{l}\text { HIV wasting } \\
\text { syndrome }\end{array}$ & 50 & 40 & 88 & $12 \mathrm{wk}$ & $\begin{array}{l}\text { Nervous system disorders: } \\
3 / 11 \text { (27) }\end{array}$ \\
\hline
\end{tabular}


randomized controlled trial studying the effects of $\Delta-9$ tetrahydrocannabinol on cancer-related anorexia-cachexia syndrome (RR 2.6I, 95\% CI 0.33-20.37). ${ }^{44}$

In the 23 randomized controlled trials, there were 4615 nonserious adverse events among people assigned to cannabinoid therapy (incidence rate I0.37 events/personyear) and I64I events among controls (incidence rate 6.87 events/person-year). Nervous system disorders was the most frequently reported category for both groups (accounting for $36.7 \%$ of events among people assigned to cannabinoids and 3 I. $3 \%$ of events among controls) (Table 3). Dizziness was the most commonly reported nonserious adverse event among cannabinoid-exposed participants; details of other nonserious adverse events are shown in Appendix 2 (available at www.cmaj.ca/cgi/content/full/I78 /I3/I669/DC2).

The incidence rate of nonserious adverse events was significantly higher among subjects assigned to cannabinoid therapy than among controls (RR I.86, 95\% CI I.57-2.2I) (Figure 2)..$^{7-12,34-51} \mathrm{We}$ found a high degree of variance among the studies (heterogeneity $\chi^{2}=187.42, p<0.001 ; I^{2}=$ $86.7 \%)$. Subgroup analysis by type of cannabinoid prepara- tion reduced the heterogeneity (Appendix 3; available at www.cmaj.ca/cgi/content/full/I78/I3/1669/DC2). The average rate of nonserious adverse events was significantly higher among people receiving oromucosal $\Delta$-9tetrahydrocannabinol-cannabidiol (RR I.88, 95\% CI I.482.39) or oral $\Delta$-9-tetrahydrocannabinol (RR 2.18, 95\% CI I.59-2.99) than among controls; there was no difference between the oral $\Delta$-9-tetrahydrocannabinol-cannabidiol and control groups (RR I.3I, 95\% CI o.88-I.96). One study had a different duration of exposure for the intervention (oral $\Delta$-9tetrahydrocannabinol-cannabidiol, 2 weeks) and placebo (I week) groups, and the incidence rate was significantly lower in the intervention group. ${ }^{51}$ Exclusion of this study increased the pooled $R R$ for oral $\Delta$-9-tetrahydrocannabinolcannabidiol from I.3I (95\% CI o.88-I.96) to I.54 (95\% CI I.I4-2.08). Further subgroup analysis by study design and study population did not significantly alter the pooled RR for nonserious adverse events for each medical cannabinoid preparation (Appendix 3; available at www.cmaj.ca/cgi /content/full/178/13/1669/DC2).

In the 8 observational studies that focused on safety issues related to medical cannabinoid preparations, ${ }^{52-59}$ a total

Table 1: Randomized controlled trials of medical cannabinoid preparations, published between 1966 and late 2007 and reporting detailed adverse event data, by mode of administration (part 2)

\begin{tabular}{|c|c|c|c|c|c|c|c|}
\hline $\begin{array}{l}\text { Mode of } \\
\text { administration; } \\
\text { study design }\end{array}$ & Reference & $\begin{array}{c}\text { Condition } \\
\text { characterizing } \\
\text { study population }\end{array}$ & $\begin{array}{l}\text { Sample } \\
\text { size }\end{array}$ & $\begin{array}{l}\text { Age, mean } \\
\text { (range), yr }\end{array}$ & $\begin{array}{l}\text { Sex, } \\
\% \text { male }\end{array}$ & $\begin{array}{l}\text { Duration of } \\
\text { exposure }\end{array}$ & $\begin{array}{l}\text { Most frequently reported } \\
\text { adverse event: } \mathrm{n} / \mathrm{N}(\%)^{*}\end{array}$ \\
\hline & Zajicek et al. ${ }^{11} \dagger$ & Multiple sclerosis & 611 & $50(18-64)$ & 34 & 37 wk & $\begin{array}{l}\text { Nervous system disorders: } \\
124 / 655 \text { (18.9) }\end{array}$ \\
\hline \multirow{7}{*}{$\begin{array}{l}\text { Crossover randomized } \\
\text { controlled trial }\end{array}$} & $\begin{array}{l}\text { Killestein } \\
\text { et al. }{ }^{47}\end{array}$ & Multiple sclerosis & 16 & 46 & NR & 4 wk & $\begin{array}{l}\text { Nervous system disorders: } \\
23 / 39 \text { (59) }\end{array}$ \\
\hline & Naef et al. ${ }^{48}$ & $\begin{array}{l}\text { Healthy, } \\
\text { cannabis-naïve } \\
\text { volunteers }\end{array}$ & 12 & $\begin{array}{l}\text { Female: } 25 \\
\text { Male: } 27\end{array}$ & 50 & $8 \mathrm{~h}$ & $\begin{array}{l}\text { Psychiatric disorders: } \\
60 / 123(48.8)\end{array}$ \\
\hline & Noyes et al. ${ }^{49}$ & $\begin{array}{l}\text { Pain associated } \\
\text { with cancer }\end{array}$ & 36 & 51 & 28 & $1 \mathrm{~d}$ & $\begin{array}{l}\text { Nervous system disorders: } \\
173 / 430(40.2)\end{array}$ \\
\hline & Orr et al. ${ }^{36}$ & $\begin{array}{l}\text { Chemotherapy- } \\
\text { induced nausea }\end{array}$ & 79 & $46(22-71)$ & 35 & $1 \mathrm{~d}$ & $\begin{array}{l}\text { Psychiatric disorders: } \\
49 / 76(64)\end{array}$ \\
\hline & Petro et al. ${ }^{50}$ & Multiple sclerosis & 9 & NR & NR & $1 \mathrm{~d}$ & $\begin{array}{l}\text { Psychiatric disorders: } \\
1 / 1(100)\end{array}$ \\
\hline & $\begin{array}{l}\text { Svendsen } \\
\text { et al. }{ }^{9}\end{array}$ & Multiple sclerosis & 24 & $50(23-55)$ & 42 & 3 wk & $\begin{array}{l}\text { Nervous system disorders: } \\
53 / 100(53)\end{array}$ \\
\hline & Vaney et al. ${ }^{51}$ & Multiple sclerosis & 57 & 54.9 & 49 & $2 w k$ & $\begin{array}{l}\text { Psychiatric disorders: } \\
21 / 45(47)\end{array}$ \\
\hline
\end{tabular}

Note: NR $=$ not reported

${ }^{*}$ Grouped by system order classes of the Medical Dictionary for Regulatory Activites. ${ }^{31}$ Data presented as number and percentage of all nonserious adverse events in the most common category.

†These 2 reports refer to the same study, with follow-up data for different periods. The total duration of the study was 52 weeks, with the first article reporting events up to the 15th week and the second article reporting events from the 16th to the 52nd week. 
of 39 serious adverse events and 3553 nonserious adverse events were reported (Table 4; and Appendix 4, available at www.cmaj.ca/cgi/content/full/178/13/r669/DC2). None of these studies had a control group. Nervous system disorders were the most frequently reported category for both serious adverse events (9 $[23.1 \%])$ and nonserious adverse events
(I4I2 [39.7\%]). Psychiatric disorders were the second frequently reported category (4 serious adverse events [I0.3\%] and 1265 nonserious adverse events [35.6\%]). The adverse events reported in observational studies are summarized in Appendix 2 (available at www.cmaj.ca/cgi/content/full/ I78/I3/I669/DC2).

Table 2: Serious adverse events (fatal and nonfatal) reported in randomized controlled trials of medical cannabinoid preparations

\begin{tabular}{|c|c|c|c|c|}
\hline \multirow[b]{2}{*}{ Serious adverse event } & \multicolumn{2}{|c|}{$\begin{array}{l}\text { Cannabinoid exposure } \\
\qquad n=164\end{array}$} & \multicolumn{2}{|c|}{$\begin{array}{c}\text { Control } \\
n=60\end{array}$} \\
\hline & No. (\%) & Rate* $^{*}$ & No. (\%) & Rate* $^{*}$ \\
\hline Respiratory, thoracic and mediastinal disorders & $27(16.5)$ & 0.06 & 7 (11.7) & 0.03 \\
\hline Dyspnea & 13 & & 3 & \\
\hline Pneumonia & $\begin{array}{c}11 \\
\text { (3 deaths) }\end{array}$ & & $\begin{array}{c}3 \\
\text { (1 death) }\end{array}$ & \\
\hline Pleural effusion & 2 & & 0 & \\
\hline Lower respiratory tract infection & 1 & & 0 & \\
\hline Pulmonary embolism & 0 & & 1 & \\
\hline Gastrointestinal disorders & $27(16.5)$ & 0.06 & $4(6.7)$ & 0.02 \\
\hline Vomiting & 16 & & 1 & \\
\hline Diarrhea & 6 & & 0 & \\
\hline Gastroenteritis & 2 & & 0 & \\
\hline Abdominal pain & 1 & & 0 & \\
\hline Constipation & 1 & & 3 & \\
\hline Duodenal ulcer & 1 & & 0 & \\
\hline Nervous system disorders & $25(15.2)$ & 0.06 & $18(30.0)$ & 0.08 \\
\hline Relapse of multiple sclerosis & 21 & & 11 & \\
\hline Convulsion & $\begin{array}{c}2 \\
\text { (1 death) }\end{array}$ & & 4 & \\
\hline Dizziness & 1 & & 0 & \\
\hline Multiple sclerosis & 1 & & 1 & \\
\hline Cerebrovascular disorder & 0 & & 2 & \\
\hline General disorders and administration-site conditions & $21(12.8)$ & 0.05 & $8(13.3)$ & 0.03 \\
\hline Death & 10 & & 1 & \\
\hline Pain & 6 & & 4 & \\
\hline Pyrexia & 5 & & 2 & \\
\hline Chest pain & 0 & & 1 & \\
\hline Renal and urinary disorders & $16(9.8)$ & 0.04 & $8(13.3)$ & 0.03 \\
\hline Urinary tract infection & 15 & & 8 & \\
\hline Hematuria & 1 & & 0 & \\
\hline Neoplasm, benign and malignant & $14(8.5)$ & 0.03 & $2(3.3)$ & 0.01 \\
\hline Neoplasm progression & 13 & & 2 & \\
\hline Cervix carcinoma & $\begin{array}{c}1 \\
\text { (1 death) }\end{array}$ & & 0 & \\
\hline Psychiatric disorders $†$ & $11(6.7)$ & 0.02 & $1(1.7)$ & $<0.01$ \\
\hline Other & $23(14.0)$ & 0.05 & $\begin{array}{c}12(20.0) \\
\text { (1 death } \neq)\end{array}$ & 0.05 \\
\hline Total & 164 & 0.37 & 60 & 0.25 \\
\hline
\end{tabular}

*Incidence rate = events/person-years. The number of person-years was 445 for cannabinoid exposure and 239 for control. †For both cannabinoid exposure and control, all events in this category were classified as "altered mood."

‡Due to myocardial ischemia. 


\section{Interpretation}

In our review, we identified $837 \mathrm{I}$ adverse events related to medical cannabinoid use, 4779 of which were reported in 23 randomized controlled trials and 3592 in 8 observational studies. Most of the events were not serious. None of the reported adverse events was unexpected, according to the International Conference on Harmonisation criteria. ${ }^{30}$

Although the randomized controlled trial is a powerful study design, several aspects of the quality of reporting of adverse events in published trials limited our results. First, not all published cannabinoid trials provided safety information; we excluded 28 randomized controlled trials, including 2 trials that examined cannabis smoked by patients with HIV infection, ${ }^{14,15}$ because they did not quantify adverse events or they reported events for only one intervention group. The Jadad score does not adequately reflect the quality of safety reporting in randomized controlled trials, which meant that rating by the Jadad scale indicated good methodologic quality for these studies, despite their poor reporting of safety. Second, most of the trials selected did not provide both the absolute number of adverse events and the number of participants reporting at least I event, as recommended by the Consolidated Standards of Reporting Trials (CONSORT) statement. ${ }^{60}$ This meant that we could focus only on the inci- dence of adverse events, rather than being able to analyze both the incidence rates of events and the risks for participants who had reported at least I event. Third, because of the lack of data on frequency of adverse events for each patient, we had to assume that the occurrence of adverse events was independent, which would not be a valid assumption if a patient had experienced more than I event (a likely scenario for nonserious adverse events). This assumption would result in generation of artificially narrow CIs around the RR estimates, which might have affected the results of significance testing.

We found 3592 adverse events reported in 8 observational studies. However, those studies were limited by lack of control groups and lack of adjustment for potential confounders, such as use of tobacco, alcohol or other recreational drugs and drug-cannabis interactions.

In our analysis, we did not include data from studies examining the synthetic cannabinoid nabilone, because this agent has different pharmacokinetic and pharmacodynamic properties, and its safety profile may differ from that of $\Delta$-g-tetrahydrocannabinol. Although nabilone is currently being used for medical purposes, we caution that our safety data cannot be extended to this drug, and the safety of nabilone must be studied separately. In addition, we excluded the 2 published randomized controlled trials of

Table 3: Frequency of nonserious adverse events reported in randomized controlled trials of medical cannabinoid preparations

\begin{tabular}{|c|c|c|c|}
\hline \multirow[b]{2}{*}{ System organ class* } & \multicolumn{2}{|c|}{ No. (\%) of nonserious adverse events } & \multirow[b]{2}{*}{$\begin{array}{l}\text { Pooled rate ratio } \\
\qquad(95 \% \mathrm{Cl})\end{array}$} \\
\hline & $\begin{array}{l}\text { Cannabinoid exposure } \\
n=4615\end{array}$ & $\begin{array}{l}\text { Control } \\
n=1641\end{array}$ & \\
\hline Nervous system disorders & $1695(36.7)$ & $513(31.3)$ & $1.87(1.53-2.30)$ \\
\hline Gastrointestinal disorders & $758(16.4)$ & $246(15.0)$ & 1.52 (1.19-1.93) \\
\hline $\begin{array}{l}\text { General disorders and administration- } \\
\text { site conditions }\end{array}$ & $651(14.1)$ & $294(17.9)$ & $1.15(1.00-1.32)$ \\
\hline Psychiatric disorders & $512(11.1)$ & $122(7.4)$ & $2.73(1.69-4.41)$ \\
\hline $\begin{array}{l}\text { Musculoskeletal, connective tissue } \\
\text { and bone disorders }\end{array}$ & $331 \quad(7.2)$ & $174(10.6)$ & $1.01(0.84-1.21)$ \\
\hline Renal and urinary disorders & $236 \quad(5.1)$ & $134 \quad(8.2)$ & $0.91(0.77-1.07)$ \\
\hline Infections and infestations & $134 \quad(2.9)$ & $70 \quad(4.3)$ & $0.96(0.73-1.26)$ \\
\hline Eye disorders & $106 \quad(2.3)$ & $16(1.0)$ & $1.97(1.23-3.17)$ \\
\hline $\begin{array}{l}\text { Injury, poisoning and procedural } \\
\text { complications }\end{array}$ & $37 \quad(0.8)$ & $11(0.7)$ & $1.25(0.73-2.14)$ \\
\hline Metabolism and nutrition disorders & $37 \quad(0.8)$ & $4 \quad(0.2)$ & $1.47(0.75-2.86)$ \\
\hline $\begin{array}{l}\text { Respiratory, thoracic and mediastinal } \\
\text { disorders }\end{array}$ & $36 \quad(0.8)$ & $7 \quad(0.4)$ & $1.42(0.77-2.62)$ \\
\hline $\begin{array}{l}\text { Skin and subcutaneous tissue } \\
\text { disorders }\end{array}$ & $30 \quad(0.7)$ & $27 \quad(1.6)$ & $0.60(0.38-0.94)$ \\
\hline Blood and lymphatic system disorders & $26 \quad(0.6)$ & $8 \quad(0.5)$ & $0.90(0.50-1.60)$ \\
\hline Cardiac disorders & $22 \quad(0.5)$ & $12(0.7)$ & $1.12(0.63-2.00)$ \\
\hline Vascular disorders & $3 \quad(0.1)$ & $2(0.1)$ & $0.69(0.32-1.51)$ \\
\hline Investigations & $1(<0.1)$ & $1 \quad(0.1)$ & $0.68(0.31-1.53)$ \\
\hline
\end{tabular}

Note: $\mathrm{Cl}=$ confidence interval.

*Classified according to Medical Dictionary for Regulatory Activities. ${ }^{31}$ 


\begin{tabular}{|c|c|}
\hline Study & Rate ratio $(95 \% \mathrm{Cl}$ \\
\hline \multicolumn{2}{|c|}{ Oromucosal spray cannabis extract $\mathrm{v}$. control } \\
\hline Berman et al. ${ }^{40}$ & $2.42(1.33-4.41)$ \\
\hline Blake et al. ${ }^{12}$ & $1.75(0.85-3.59)$ \\
\hline Collin et al..$^{38}$ & $1.86(1.35-2.55)$ \\
\hline Nurmikko et al. ${ }^{7}$ & $2.55(1.77-3.67)$ \\
\hline Rog et al. ${ }^{8}$ & $2.09(1.31-3.33)$ \\
\hline Tomida et al. ${ }^{37}$ & $1.50(0.51-4.43)$ \\
\hline Wade et al. ${ }^{41}$ & $0.74(0.41-1.34)$ \\
\hline Wade et al..$^{39}$ & $2.11(1.52-2.93)$ \\
\hline Subtotal & $1.88(1.48-2.39)$ \\
\hline \multicolumn{2}{|c|}{ Oral $\Delta$-9-tetrahydrocannabinol-cannabidiol v. control } \\
\hline Carroll et al. ${ }^{46}$ & $2.53(1.39-4.60)$ \\
\hline Killestein et al. ${ }^{47}$ & $2.31(1.20-4.42)$ \\
\hline Strasser et al. ${ }^{44}$ & $1.12(0.77-1.63)$ \\
\hline Vaney et al..$^{51}$ & $0.56(0.37-0.86)$ \\
\hline Zajicek et al. ${ }^{10,11}$ & $1.36(1.25-1.48)$ \\
\hline Subtotal & $1.31(0.88-1.96)$ \\
\hline \multicolumn{2}{|c|}{ Oral $\Delta$-9-tetrahydrocannabinol v. control } \\
\hline Buggy et al. ${ }^{42}$ & $1.08(0.79-1.47)$ \\
\hline Frytak et al. ${ }^{43}$ & $3.70(2.34-5.85)$ \\
\hline Killestein et al. ${ }^{47}$ & $0.69(0.30-1.62)$ \\
\hline Naef et al. ${ }^{48}$ & $4.39(2.91-6.62)$ \\
\hline Neidhart et al. ${ }^{34}$ & $1.90(1.38-2.61)$ \\
\hline Noyes et al. ${ }^{35}$ & $4.54(2.73-7.55)$ \\
\hline Noyes et al. ${ }^{49}$ & $2.50(1.98-3.15)$ \\
\hline Orr et al. ${ }^{36}$ & $8.44(4.23-16.85)$ \\
\hline Strasser et al. ${ }^{44}$ & $1.40(0.97-2.03)$ \\
\hline Svendsen et al. ${ }^{9}$ & $2.63(1.81-3.82)$ \\
\hline Timpone et al. ${ }^{45}$ & $1.24(0.54-2.85)$ \\
\hline Zajicek et al. ${ }^{10,11}$ & $1.32(1.21-1.43)$ \\
\hline Petro et al..$^{50}$ & $0.50(0.03-7.98)$ \\
\hline Subtotal & $2.18(1.59-2.99)$ \\
\hline Overall & $1.86(1.57-2.21)$ \\
\hline
\end{tabular}

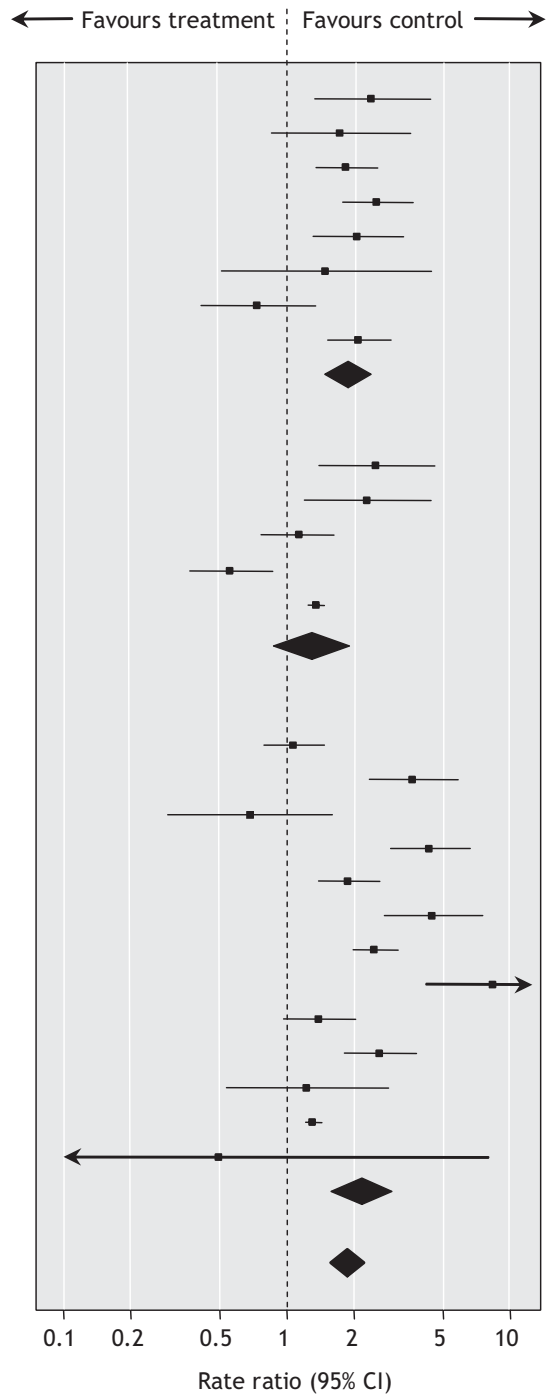

Figure 2: Incidence rates and rate ratios (random-effects model) for nonserious adverse events among participants assigned to medical cannabinoid therapy or control in 23 randomized controlled trials. Dotted vertical line represents no difference between the intervention and the control. $\mathrm{Cl}=$ confidence interval.

smoked cannabis because of a lack of quantifiable adverse event data. ${ }^{14,15}$ Given the extent of legal use of medical cannabis and the potential risks associated with administration by smoking, good-quality safety and efficacy data on smoked cannabis are urgently needed. We also caution against assuming that the adverse effects of recreational cannabis use can be expected to occur with medical cannabinoid use. The amounts used, the existence of comorbidities and the methods of drug delivery are different in the 2 populations, which should therefore be evaluated separately.

We found that the rate of nonserious adverse events was I.86 times higher among medical cannabinoid users than among controls. However, we did not find a higher incidence rate of serious adverse events associated with medical cannabinoid use. The fact that $99 \%$ of the serious adverse events from randomized controlled trials were reported in only 2 trials suggests that more studies with long-term exposure are required to further characterize safety issues. Such studies are crucial to detect rare adverse events and to address specific concerns regarding the development of tolerance and the development of cognitive and behavioural effects of medical cannabinoid use. The findings of our systematic review may stimulate future high-quality controlled observational studies and clinical trials to explore the safety of medical cannabinoid use. We believe that systematic collection of data related to adverse events associated with cannabis use should continue, and the results should be made publicly available, to assist in clinical, regulatory and political decision-making. 
Table 4: Frequency of nonserious adverse events reported in observational studies of medical cannabinoid preparations

\section{No. (\%) of nonserious} adverse events

System organ class* $n=3553$

\begin{tabular}{|c|c|}
\hline Nervous system disorders & $1412(39.8)$ \\
\hline Psychiatric disorders & $1265(35.6)$ \\
\hline Gastrointestinal disorders & $558(15.7)$ \\
\hline Vascular disorders & $141(4.0)$ \\
\hline Cardiac disorders & $107(3.0)$ \\
\hline $\begin{array}{l}\text { General disorders and } \\
\text { administration-site conditions }\end{array}$ & $42(1.2)$ \\
\hline Investigations & $13(0.4)$ \\
\hline $\begin{array}{l}\text { Injury, poisoning and procedural } \\
\text { complications }\end{array}$ & $7 \quad(0.2)$ \\
\hline Eye disorders & $6 \quad(0.2)$ \\
\hline $\begin{array}{l}\text { Respiratory, thoracic and } \\
\text { mediastinal disorders }\end{array}$ & $2(0.1)$ \\
\hline
\end{tabular}

${ }^{*}$ Classified according to Medical Dictionary for Regulatory Activities. ${ }^{31}$

This article has been peer reviewed.

Competing interests: Mark Ware has received funds in the form of grants and consultancy and speaker fees from pharmaceutical companies involved in developing and marketing cannabinoid drugs, including AstraZeneca, Bayer, Cannasat, GW Pharmaceuticals, Solvay and Valeant; however, he has no financial interest in, nor is he an employee of, any of these companies. No competing interests declared for Tongtong Wang, Jean-Paul Collet or Stan Shapiro.

Contributors: All of the authors conceived of and designed the study and were responsible for analyzing and interpreting the data. Tongtong Wang was responsible for acquiring the data. Tongtong Wang and Mark Ware had full access to all of the data in the study and had final responsibility for the decision to submit for publication. All of the authors collaborated in drafting and revising the manuscript for important intellectual content, and all approved the final version for publication.

Acknowledgements: We thank Aihua Liu, MSc, Department of Epidemiology and Biostatistics, McGill University, for her assistance in scoring the quality of studies.

This research was supported by the Canadian Institutes of Health Research (grant no. MOL66262). Mark Ware is funded by a clinician-scientist award from the Fonds de la recherche en santé du Québec and by the Louise and Alan Edwards Foundation.

\section{REFERENCES}

I. World drug report. New York: United Nations, Office on Drugs and Crime; 2007.

2. Mechoulam R. The pharmacohistory of Cannabis sativa. In: Mechoulam R, editor. Cannabinoids as therapeutic agents. Boca Raton (FL): CRC Press; I986. p. I-I9.

3. Beaulieu P, Ware M. Reassessment of the role of cannabinoids in the management of pain. Curr Opin Anaesthesiol 2007;20:473-7.

4. Marihuana Medical Access Regulations, SOR/oI-227, 200I. Available: http://laws .justice.gc.ca/en/C-38.8/SOR-200I-227/text.html (accessed 2008 Mar 26)

5. Publication of the regulations amending the Marihuana Medical Access Regulations (MMAR). Ottawa: Health Canada; 2005 Sep I4. Available: www.hc-sc.gc.ca /dhp-mps/pubs/precurs/mmar-ramm_e.html (accessed 2008 Mar 26).

6. Tramer MR, Carroll D, Campbell FA, et al. Cannabinoids for control of chemotherapy induced nausea and vomiting: quantitative systematic review. BMJ 200I;323: I6-2I.

7. Nurmikko TJ, Serpell MG, Hoggart B, et al. Sativex successfully treats neuropathic pain characterised by allodynia: a randomised, double-blind, placebo-controlled clinical trial. Pain 2007;133:210-20.

8. Rog DJ, Nurmikko TJ, Friede T, et al. Randomized, controlled trial of cannabisbased medicine in central pain in multiple sclerosis. Neurology 2005;65:812-9.
9. Svendsen KB, Jensen TS, Bach FW. Does the cannabinoid dronabinol reduce central pain in multiple sclerosis? Randomised double blind placebo controlled crossover trial. BMJ 2004;329:253-7.

Io. Zaiicek J, Fox P, Sanders H, et al. Cannabinoids for treatment of spasticity and other symptoms related to multiple sclerosis (CAMS study): multicentre randomised placebo-controlled trial. Lancet 2003;362:1517-26.

II. Zajicek JP, Sanders HP, Wright DE, et al. Cannabinoids in multiple sclerosis (CAMS) study: safety and efficacy data for 12 months follow up. J Neurol Neurosurg Psychiatry 2005;76:1664-9.

I2. Blake DR, Robson P, Ho M, et al. Preliminary assessment of the efficacy, tolerability and safety of a cannabis-based medicine (Sativex) in the treatment of pain caused by rheumatoid arthritis. Rheumatology 2006;45:50-2.

13. Skrabek RQ, Galimova L, Ethans K, et al. Nabilone for the treatment of pain in fibromyalgia. J Pain 2008;9:I64-73.

I4. Abrams DI, Hilton JF, Leiser RJ, et al. Short-term effects of cannabinoids in patients with HIV-I infection: a randomized, placebo-controlled clinical trial. Ann Intern Med 2003;I39:258-66.

15. Abrams DI, Jay CA, Shade SB, et al. Cannabis in painful HIV-associated sensory neuropathy: a randomized placebo-controlled trial. Neurology 2007;68:515-2I.

I6. Stakeholder statistics. Ottawa (ON): Health Canada. Available: www.hc-sc.gc.ca /dhp-mps/marihuana/stat/index_e.html (accessed 2008 Mar 25).

17. Avorn J. In defense of pharmacoepidemiology — embracing the yin and yang of drug research. N Engl J Med 2007;357:2219-2I.

I8. Ray WA. Population-based studies of adverse drug effects. N Engl J Med 2003; 349:1592-4.

19. Ware MA, Tawfik VL. Safety issues concerning the medical use of cannabis and cannabinoids. Pain Res Manag 2005; Io Suppl A:3IA-37A.

20. Kalant $\mathrm{H}$. Adverse effects of cannabis on health: an update of the literature since 1996. Prog Neuropsychopharmacol Biol Psychiatry 2004;28:849-63.

2I. Hall W, Solowij N. Adverse effects of cannabis. Lancet I998;352:I6II-6.

22. Ashton $\mathrm{CH}$. Adverse effects of cannabis and cannabinoids. Br J Anaesth $1999 ; 83$ : $637-49$.

23. Campbell FA, Tramer MR, Carroll D, et al. Are cannabinoids an effective and safe treatment option in the management of pain? A qualitative systematic review. $B M$ ) 200I;323:13-6.

24. Russo E, Mathre ML, Byrne A, et al. Chronic cannabis use in the Compassionate Investigational New Drug Program: an examination of benefits and adverse effects of legal clinical cannabis. J Cannabis Ther 2002;2:3-57.

25. Moore TH, Zammit S, Lingford-Hughes A, et al. Cannabis use and risk of psychotic or affective mental health outcomes: a systematic review. Lancet 2007;370: 319-28.

26. Hashibe M, Straif K, Tashkin DP, et al. Epidemiologic review of marijuana use and cancer risk. Alcohol 2005;35:265-75

27. Grant I, Gonzalez R, Carey CL, et al. Non-acute (residual) neurocognitive effects of cannabis use: a meta-analytic study. J Int Neuropsychol Soc 2003;9:679-89.

28. Jadad AR, Moore RA, Carroll D, et al. Assessing the quality of reports of randomized clinical trials: Is blinding necessary? Control Clin Trials 1996;17:I-I2.

29. Downs SH, Black N. The feasibility of creating a checklist for the assessment of the methodological quality both of randomised and non-randomised studies of health care interventions. J Epidemiol Community Health 1998;52:377-84.

30. ICH Steering Committee. ICH harmonised tripartite guideline. Clinical safety data management: definitions and standards for expedited reporting E2A. Step 4 version. International Conference on Harmonisation of Technical Requirements fo Registration of Pharmaceuticals for Human Use; 1994. Available: www.ich.org /LOB/media/MEDIA436.pdf (accessed 2008 Mar 25).

3I. Medical dictionary for regulatory activities. Version io.o. Los Angeles: Northrop Grumman Corporation; 2008. Available (by subscription): www.meddramsso .com/ (accessed 2008 Mar 25).

32. Sutton AJ, Abrams KR, Jones DR, et al. Methods for meta-analysis in medical research. Chichester (UK): Wiley; 2000.

33. Higgins JPT, Thompson SG. Quantifying heterogeneity in a meta-analysis. Stat Med 2002;2I:1539-58.

34. Neidhart JA, Gagen MM, Wilson HE, et al. Comparative trial of the antiemetic effects of THC and haloperidol. JClin Pharmacol ig8I;2I (8-9 Suppl):38S-42S.

35. Noyes R Jr, Brunk SF, Baram DA, et al. Analgesic effect of delta-9-tetrahydrocannabinol. J Clin Pharmacol I975;15:139-43.

36. Orr LE, McKernan JF. Antiemetic effect of delta 9-tetrahydrocannabinol in chemotherapy-associated nausea and emesis as compared to placebo and compazine. I Clin Pharmacol I98I; 2 I (8-9 Suppl):76S-8oS.

37. Tomida I, Azuara-Blanco A, House H, et al. Effect of sublingual application of cannabinoids on intraocular pressure: a pilot study. J Glaucoma 2006;15:349-53.

38. Collin C, Davies P, Mutiboko IK, et al. Randomized controlled trial of cannabisbased medicine in spasticity caused by multiple sclerosis. Eur J Neurol 2007; I4: 290-6.

39. Wade DT, Makela P, Robson P, et al. Do cannabis-based medicinal extracts have general or specific effects on symptoms in multiple sclerosis? A double-blind, randomized, placebo-controlled study on I6o patients. Mult Scler 2004;I0:434-4I.

40. Berman JS, Symonds C, Birch R. Efficacy of two cannabis based medicinal extracts for relief of central neuropathic pain from brachial plexus avulsion: results of a randomised controlled trial. Pain 2004;112:299-306.

4I. Wade DT, Robson P, House H, et al. A preliminary controlled study to determine whether whole-plant cannabis extracts can improve intractable neurogenic symptoms. Clin Rehabil 2003;17:2I-9.

42. Buggy DJ, Toogood L, Maric S, et al. Lack of analgesic efficacy of oral delta-9- 
tetrahydrocannabinol in postoperative pain. Pain 2003;106:169-72.

43. Frytak S, Moertel CG, O'Fallon JR, et al. Delta-g-tetrahydrocannabinol as an antiemetic for patients receiving cancer chemotherapy. A comparison with prochlorperazine and a placebo. Ann Intern Med 1979;91:825-30.

44. Strasser F, Luftner D, Possinger K, et al. Comparison of orally administered cannabis extract and delta-g-tetrahydrocannabinol in treating patients with cancerrelated anorexia-cachexia syndrome: a multicenter, phase III, randomized, double-blind, placebo-controlled clinical trial from the Cannabis-In-Cachexia-StudyGroup. J Clin Oncol 2006;24:3394-400.

45. Timpone JG, Wright DJ, Li N, et al; the DATRI oo4 Study Group. The safety and pharmacokinetics of single-agent and combination therapy with megestrol acetate and dronabinol for the treatment of HIV wasting syndrome. AIDS Res Hum Retroviruses 1997;13:305-15.

46. Carroll CB, Bain PG, Teare L, et al. Cannabis for dyskinesia in Parkison disease: randomized double-blind crossover study. Neurology 2004;63:1245-50.

47. Killestein J, Hoogervorst ELJ, Reif M, et al. Safety, tolerability, and efficacy of orally administered cannabinoids in MS. Neurology 2002;58:I404-7.

48. Naef M, Curatolo M, Petersen-Felix S, et al. The analgesic effect of oral delta-9tetrahydrocannabinol (THC), morphine, and a THC-morphine combination in healthy subjects under experimental pain conditions. Pain 2003;105:79-88.

49. Noyes R Jr, Brunk SF, Avery DA, et al. The analgesic properties of delta-9-tetrahydrocannabinol and codeine. Clin Pharmacol Ther 1975;18:84-9.

50. Petro DJ, Ellenberger C Jr. Treatment of human spasticity with delta 9-tetrahydrocannabinol. J Clin Pharmacol I98I;2I (8-9 Suppl):4I3S-4I6S.

51. Vaney C, Heinzel-Gutenbrunner M, Jobin P, et al. Efficacy, safety and tolerability of an orally administered cannabis extract in the treatment of spasticity in patients with multiple sclerosis: a randomized, double-blind, placebo-controlled, crossover study. Mult Scler 2004;10:417-24.

52. Attal N, Brasseur L, Guirimand D, et al. Are oral cannabinoids safe and effective in refractory neuropathic pain? Eur J Pain 2004;8:173-7.

53. Devine ML, Dow GJ, Greenberg BR. Adverse reactions to delta-9-tetrahydrocannabinol given as an antiemetic in a multicenter study. Clin Pharm 1987;6:319-22.

54. Hagenbach U, Luz S, Ghafoor N, et al. The treatment of spasticity with delta-9tetrahydrocannabinol in persons with spinal cord injury. Spinal Cord 2007;45:551-62.

55. Holdcroft A, Maze M, Dore C, et al. A multicenter dose-escalation study of the analgesic and adverse effects of an oral cannabis extract (Cannador) for postoperative pain management. Anesthesiology 2006;104:1040-6.

56. Nelson K, Walsh D, Deeter P, et al. A phase II study of delta-g-tetrahydrocannabinol for appetite stimulation in cancer-associated anorexia. J Palliat Care 1994; IO:I4-8.

57. Rog DJ, Nurmikko TJ, Young CA. Oromucosal delta-9-tetrahydrocannabinol/ cannabinol for neuropathic pain associated with multiple sclerosis: an uncontrolled, open-label, 2-year extension trial. Clin Ther 2007;29:2068-79.

58. Vinciguerra V, Moore T, Brennan E. Inhalation marijuana as an antiemetic for cancer chemotherapy. N Y State J Med I988;88:525-7.

59. Wade DT, Makela PM, House H, et al. Long-term use of a cannabis-based medicine in the treatment of spasticity and other symptoms in multiple sclerosis. Mult Scler 2006;12:639-45.

6o. The CONSORT Statement. Available: www.consort-statement.org/?o=IoII (accessed 2008 Mar 25).

Correspondence to: Dr. Mark A. Ware, Alan Edwards Centre for Research on Pain, Rm. EIg.I45, Montréal General Hospital, I650 Cedar Ave., Montréal QC H3G IA4; fax 5I4 934-849I; mark.ware@mail.mcgill.ca 